\title{
Men's Participation in Using the Vasectomy Contraception Method
}

\author{
Ilham Syahputra \\ \{solid_sos@yahoo.co.id\} \\ Social Anthropology, Postgraduate Program, Universitas Negeri Medan, Indonesia
}

\begin{abstract}
This study aimed to determine how men's participation in using the vasectomy contraceptive method in TanjungMorawa District Deli Serdang Regency. This research was conducted through qualitative research with a descriptive approach. The research informants were determined by using a purposive sampling technique by involving a married couple who used the vasectomy contraceptive method and family planning, counselors. Data collection techniques were done through interviews, observation and documentation study. The results showed that there were socio-cultural factors that influence men's participation in family planning programs, namely the existence of gender inequality where there was an assumption that family planning was the only women's care. When men use vasectomy contraception, social stereotypes emerge to consider that men as stupid husbands and wives were believed who did not comply with their husbands. Having men participating as contraception users will create new construction in the household so that family planning is no longer synonymous with women's care, but men can also participate in it.
\end{abstract}

Keywords: Men's Participation, Vasectomy, Gender

\section{Introduction}

The population issue and family planning have become a national issue in Indonesia since the signing of the Declaration of Population by President Soeharto in 1968. Since then the family planning $(\mathrm{KB})$ program was introduced to the community to control fertility levels to support national development. In its journey, the family planning program experienced various obstacles such as collisions with the socio-cultural values of the community. The existence of cultural values in the community in the choice of children's gender has hampered the implementation of the family planning program. In almost all societies, the necessity of having sons for economic, social and religious reasons is still very strong. The desire to have a minimum number of boys will affect the fertility behavior of partners [1]. Besides, the culture of Indonesian people who are accustomed to living in large families will make it difficult to accept family planning programs that carry the concept of a small family.

The implementation of the family planning program also deals with issues of gender roles between men and women. The notion that family planning is identical to women is a mistaken assumption because family planning is also a matter for men. This condition causes many men are ashamed to be involved even though the husband's support to his wife is proven to have a big influence on the wife's compliance using contraception [2]. Besides, the active participation of men in the use of contraception is also needed to support the population development program. Based on survey data conducted by the Population and Family 
Planning Agency in 2018, it shows that in Indonesia the use of men contraceptive methods such as vasectomy is only $0.3 \%$ and condoms are $3.0 \%$ [3]. This condition shows that men's participation in using contraceptive in Indonesia is still very low when compared to other countries such as Iran (12\%), Tunisia (16\%), Malaysia (11\%) and the United States (32\%) so efforts are quietly needed encourage such participation [4].

Vasectomy as a contraceptive method is a medical procedure in the form of a small operation performed on men by cutting and binding the vas deferens channel (sperm transport channel from the testis to the penis) so that sperm cannot flow during ejaculation. Vasectomy or sterilization is a very effective procedure to prevent pregnancy because it is permanent with a very high success rate. Vasectomy contraceptive method also does not cause erectile disorders, and does not affect sexual libido and is inexpensive because once surgery can be effective forever [5]. However, the use of this kind of contraception in Indonesia is still very low. The issue of family planning is related to social construction in the family. According to Abdullah [6], social construction is highly dependent on values in life because each group has its value relativity. However, the existence of openness can cause cultural boundaries that are influenced by group values to become liquid, thus encouraging the redefinition of individual and group identities.

The changes in group values can occur through social deconstruction because the culture is not something that is inherited and practiced together but is situational so that it can be changed. Gender role in the household is also not an absolute thing but can be deconstructed as needed. The results of Chomsatun et.al [5] research on vasectomy concluded that men who used vasectomy contraception as a form of resistance to gender injustice were so far only women who were required to use contraception. Men used vasectomy contraception as a form of the virility of a husband to his wife. The research of Ardiana et al. [7] concluded that the high number of male participation using the contraceptive method was due to the existence of social support from the community. The community accepted the vasectomy contraceptive method as the choice of each individual in their social environment. Based on the description above, the authors assume the need to conduct this research on how socio-cultural factors affect men's participation in the use of the vasectomy contraception method?

\section{Research method}

This research was conducted through qualitative research with a descriptive approach. The informants in this study were determined based on purposive sampling technique [8]. Informants were chosen based on their ability to provide information to answer the problem formulation in this study. Informants in this study amounted to 5 people consisting of 2 married couples using the vasectomy contraceptive method and 1 family planning counselor. In this research, the data were collected through in-depth interviews, observations and documentation studies. Data analysis in this research was carried out by reducing data, categorizing data, synthesizing and formulating certain statements. The data obtained in this study will identify any data that has meaning and relationship with the focus and problem of the research. This research was conducted in Tanjung Morawa, Deli Serdang Regency, North Sumatra.

\section{Result and discussion}


Men used the vasectomy contraceptive method was affected by the presence of the wife's health when using contraception. The existence of health problems in the form of black spots on the face of his wife and fears of other health problems due to daily pill consumption affected the husband looked for alternative options for using certain methods of contraception to prevent pregnancy. This is as conveyed by Yusuf Armadi as an informant as follows: "I want to use vasectomy contraception because my wife has a health problem using pills. I'm also so sad if my wife must take pills every day..."

Besides the wife's health condition, other reasons caused the husband (men) to use the vasectomy contraceptive method. The low success rate of using contraceptive pills in preventing pregnancy was also as husbands' reason to use the vasectomy contraceptive method. As conveyed by Sidik as informant below: "...when my wife used (using) the pill, she got pregnant too. So I think what if I use contraception because my wife is not suitable to use the pill..."

This study involved two families who were using the vasectomy contraceptive method. The first family (Sidik) has been using vasectomy contraception since 2010 while the second family (Yusuf Armadi) has been using vasectomy contraception since 2008. Both families have differences in getting information about vasectomy. The first family obtained vasectomy information from a family planning counselor who made a personal approach, while the second family obtained vasectomy information from the mass media and the internet.

Based on socioeconomic status, vasectomy users can be divided into two groups, namely families with lower economic levels and families with a medium economic level. The first family had a job as a construction worker while the second family had a job as a provider of vehicle documentation services and the wife of the two families was only a housewife. There was a difference in the economic level of families using vasectomy contraceptive methods as conveyed by family planning instructor (Burhanuddin) as follows: "...those who use vasectomy contraception work as pedicab drivers, construction workers, but some work in offices..."

Considering the education level, the families who used vasectomy could be divided into two groups, namely families with secondary education level and families with higher education levels. The first family graduated from a high school education while the second family graduated as a Diploma 3 degree. The wives of both families graduated from high school education. Based on data taken from the Center for Family Planning Extension Services in TanjungMorawa obtained the following information in Table 1 below.

Tabel 1. Contraception use rates

\begin{tabular}{ccc}
\hline $\begin{array}{c}\text { Contraception } \\
\text { Types }\end{array}$ & $\begin{array}{c}\text { Number of } \\
\text { Active } \\
\text { Members }\end{array}$ & $\%$ \\
\hline Spiral/IUD & 2.138 & 7.1 \\
Tubectomy & 1.199 & 4.0 \\
Vasectomy & 587 & 2.0 \\
Condom & 2.937 & 9.8 \\
Implant & 3.033 & 10.1 \\
Injection & 9.632 & 32.1 \\
Pills & 10.413 & 34.7 \\
Total & 29.939 & 100 \\
\hline
\end{tabular}

Source: Family Planning Agency in Tanjung Morawa, 2019 
Based on the data above, it can be concluded that the level of men's participation in the use of the vasectomy contraceptive method in TanjungMorawa is high or above the national achievement which is only $0.3 \%$. It showed that vasectomy is a method of contraception that is popular with men in this area. The issue of family planning was related to the gender roles of men and women in the household. Family planning had been identified with women's care because of their inherent reproductive functions such as pregnancy, childbirth, and breastfeeding. Therefore, women were considered as the main target in the implementation of the family planning program so far.

This condition lasted a long time and being constructed until now. When men participated in family planning as users of the contraceptive method were still considered taboo and the social environment tends to negative view for those who used the vasectomy contraceptive method. This is as stated by Sidik as an informant as follows:"... at that time I wanted to take a vasectomy, but my friends said no and I was ridiculed, he said stupid if a man wanted to use contraception..." The same information was also stated by informant Yusuf Armadi as follows: "... nobody in this environment knows that I use a vasectomy. It's still taboo here regarding vasectomy. It is considered strange if there are men who have vasectomies ..."

Stereotypes related to the participation of men as users of vasectomy contraception method were not only attached to the man, but also the wife as a partner. The wives (women) were considered as the person that had responsibility for the use of contraception, not the husbands (men). When men in the household use contraception, the surrounding community judged their wives as irresponsible people. The social environment gave certain stereotypes to the wives (women) whose husbands used the vasectomy contraceptive method. Stereotypes were inherent such as a wife who did not obey her husband, a wife who was cruel and mean to a husband. Those were stated by informant Ani Irawati as follows: "...when my husband joined a vasectomy, all moms here told (said) why a husband should use contraception, what is his wife's duty..." Those conditions showed that women were still constructed as the person who was responsible for the use of contraception and the use of contraception is considered as a form of wife's compliance with the husband in the household.

There were differences in family characteristics using the vasectomy contraceptive method. Considering the socioeconomic status, there were families with low and medium economic levels who use vasectomy contraception methods. Thus, it can be concluded that there is no influence of socioeconomic status in the use of vasectomy contraceptive methods. The difference in the family's economic level is not a benchmark in the selection of the vasectomy contraceptive method.

Based on the family education level, there were families with secondary and tertiary education using vasectomy contraception. Thus it can be concluded that the level of education does not affect the use of vasectomy contraceptive methods. The difference in education level is not a benchmark in the selection of vasectomy contraception methods, but the level of education influences access to information about vasectomy where families with higher education levels have easier access to the information about vasectomy from printed and electronic media.

The acceptance of the social environment against vasectomy contraception is influenced by the social construction of the community in certain environments. However, the existence of openness can cause cultural boundaries that are influenced by group values to become liquid, thus encouraging the redefinition of individual and group identities. This is what happens to men who use the vasectomy contraceptive method. With men participating as contraceptive users a new construction emerges in the household so that family planning is no longer synonymous with women's affairs, but men can also participate in it. 
In contrast to the results of the Chomsatun et al. research (2013) which concluded that men who used vasectomy contraception as a form of resistance to gender injustice and men use vasectomy contraception as a form of the virility of a husband to his wife. So in the context of this study, the wife's health factors and the failure of contraceptive use by the wife are factors that encourage men to use vasectomy contraception. The existence of health problems and pregnancy due to the failure of contraceptive use has "forced" men to use vasectomy contraception. Thus, men unwillingly have deconstructed their gender roles in the household.

\section{Conclusion}

Men's participation in the use of contraception is very necessary to support a genderresponsive family planning program. With the increasing level of male participation in family planning program, it will be able to eliminate the stigma against women as the main target of the program. Men and women have the same right and obligation to maintain their reproduction health under their respective health characteristics so that the choice of contraceptive method is a joint choice of husband and wife that must be adapted to the needs of the family.

The social environment plays a big role in accepting innovations in reproduction health. Therefore, openness is needed in accepting new elements by the community so that the dichotomy of gender roles can be changed according to the needs of the community. Culture is not rigid but can be reconstructed according to the needs and development of the era.

\section{References}

[1] Lucas, David, Peter McDonald, Elspeth Young, Christabel Young. 1990. Pengantar Kependudukan. Terjemahan Nin Bakdi Sumanto, Riningsih Saladi. Yogyakarta: Gadjah Mada University Press.

[2] Rafidah, Ida and Arief Wibowo. 2012. Pengaruh Dukungan Suami Terhadap Kepatuhan Akseptor Melakukan KB Suntik. Surabaya: Jurnal Biometrika dan Kependudukan Vol. 1 No. 1, 72-78.

[3] BKKBN. 2018. Survei Kinerja Akuntabilitas Program (SKAP).Jakarta: BKKBN

[4] Rizkitama, Afnita Ayu and Fitri Indrawati. 2015. Hubungan Pengetahuan, Persepsi, Sosial Budaya Dengan Peran Aktif Pria Dalam Vasektomi di Kecamatan Paguyangan Kabupaten Brebes tahun 2011-2012. Semarang: Unnes Journal of Public HealthVol 4 No. 1, 48-54.

[5] Chomsatun, Hadiyantidan Martinus Legowo. 2013. Vasektomi Sebagai 'Counter Gender Inequality'. Surabaya: Jurnal Paradigma Vol. 1 No. 2 : 16-21.

[6] Abdullah, Irwan. 2015. Konstruksi dan Reproduksi Kebudayaan. Yogyakarta: Pustaka Pelajar.

[7] Ardiana, Yudi, Pande Putu Januraga, I Nyoman Mangku Karmaya. 2015. Faktor Yang Berperan Pada Penerimaan Kontrasepsi Vasektomi di Kabupaten Lombok. Denpasar: Jurnal Public Health and Preventive Medicine Archive Vol 3 No. 2, 173-177.

[8] Moleng, Lexy. (2005). Metodologi Penelitian Kualitatif. Bandung: PT. RemajaRosdakarya. 